\title{
CORPORATIONS AS WHISTLEBLOWERS IN THE CRIME OF DEFAMATION BASED ON THE ELECTRONIC AND TRANSACTION INFORMATION ACT
}

\author{
Dwikarunia Setiawan Guntik ${ }^{1}$, Dewa Gede Pradnya Yustiawan ${ }^{2}$ \\ ${ }^{1,2}$ Faculty of Law, Universitas Udayana \\ Email: ${ }^{1)}$ guntikdua@gmail.com, ${ }^{2)}$ pradnya_yustiawan@unud.ac.id
}

\begin{abstract}
The purpose of writing this article is to find out whether the corporation can be a reporting party in the criminal act of defamation under the ITE Law. The methods performed in writing this article are normative legal research methods that use a type of statutory approach and a conceptual approach. The results of the study showed that the regulation of defamation crimes stipulated in the Criminal Code and ITE Law, corporations cannot be the reporting party in the criminal act of defamation under the ITE Law because based on letter a guidelines for the implementation of Article 27 Paragraph (3) of SkB No. 2/VI/2021 on guidelines for the implementation of the ITE Law stipulate that the understanding of the content of insults and / or defamation must refer to the provisions of Article 310 and 311 of the Criminal Code in addition to letter $f$ The implementation guidelines of Article 27 Paragraph (3) of the ITE Law stipulates that victims who can become whistleblowers are only individuals with a specific identity so that corporations cannot be reporting parties under the ITE Law. Corporations cannot be the reporting party should be included in the article explanation to be binding in an arrangement because the nature of the DECREE containing implementation guidelines is only binding on law enforcement only.
\end{abstract}

Keywords: Corporations, Defamation, Information and Electronic Transactions Act

\section{INTRODUCTION}

Indonesia is a state of law; nonetheless, there are numerous legal restrictions that protect the community's interests; one of these regulations is the KUHP (hereinafter referred to as the Criminal Code). The Criminal Code is a collection of laws that provide restrictions that apply in Indonesia to protect the community's interests. Defamation is one of the topics covered in the Criminal Code. Generally, defamation is prohibited under Article 310 (1) of the Criminal Code, which has the following article formulation: 
"Whoever intentionally offends someone person's honor or character by accusing them of something, the intent of which is apparent so that it is known to the public, faces a maximum sentence of nine months in prison or a maximum fine of four thousand five hundred rupiahs for libel."

Nowadays acts of defamation are often carried out through the internet, defaming through the internet can be said to be cybercrime (Supanto, 2016). Cybercrime is one of the new crimes that is significantly developing, both in terms of the modus operandi and the form of the crime (Maskun, 2013). Cybercrime is typically committed via computers or cell phones. The information and communication technology (ICT) mediums facilitate global connectivity. Today, practically all activities that connect humans may be conducted via the internet, and Indonesia is one of the top 10 (ten) countries in the world with the most smartphone users. In 2014, there were 57.7 million smartphone users; this figure increased to 71.6 million in 2015 , and has continued to grow significantly till it is estimated to reach 100 million in 2017 (Samudra, 2020). The modus operandi of crime continues to develop along with the development of human civilization, cyber crime is an activity that uses a computer as a medium that is supported by a telecommunications system. The regulation of cyber crime in Indonesia's positive law is regulated in Law Number 19 of 2016 concerning Amendments to Law Number 11 of 2008 concerning Information and Electronic Transactions (hereinafter referred to as UU ITE) and one form of cybercrime stipulated in the ITE Law is defamation.

Meanwhile, if the defamation is carried out through an internet platform, then the regulation that regulates it is Article 27 paragraph (3) of the ITE Law with the formulation of the article as follows:

"Everyone who distributes and/or transmits and/or makes accessible Electronic Information and/or Electronic Documents intentionally and without authority faces a charge of contempt and/or defamation."

Those who violate the provisions above will be subject to criminal sanctions in the form of imprisonment for a maximum of 6 (six) years and/or a fine of a maximum of Rp. $1,000,000,000.00$ (one billion rupiah) in accordance with the provisions of Article 45 paragraph (1) of the ITE Law.

The case of defamation carried out through an internet platform that was widely discussed was the case of Prita Mulyasari. Prita Mulyasari was charged with Article 27 Paragraph (3) Jo. Article 45 Paragraph (1) of the ITE Law, Article 310 Paragraph (2) of the Criminal Code, and Article 311 Paragraph (1) of the Criminal Code after pouring out his complaints against the OMNI International Hospital which was poured out via E-mail, which was deemed to have defamed the Hospital OMNI International, after that OMNI International reported Prita Mulyasari on charges of defamation. Based on the case of Prita Mulyasari, the question arises whether a corporation can be a whistleblower in a defamation case carried out through social media.

Therefore, this study aims to (1) identify and analyze the regulation of criminal acts of defamation in the prevailing laws and regulations in positive law (2) identify whether corporations can be the reporting party in criminal acts of defamation based on the ITE Law. 


\section{RESEARCH METHOD}

The writing of this scientific paper uses the type of normative research. Normative legal research is legal research that has a concept as what has been written in laws and regulations, rules, and norms that become the benchmark for human behavior (Samudra, 2020). The type of approach in writing is to use a statutory approach and a conceptual approach. The technique of tracing legal materials uses the library method and grammatical interpretation with the aim of providing an interpretation of the words contained in the legislation.

\section{RESULT AND DISCUSSION}

\subsection{Regulation of the Criminal Acts of Defamation in the Legislation that is currently applied in Indonesia}

\subsubsection{KUHP}

The criminal act of defamation is regulated in CHAPTER XVI concerning Humiliation, precisely with the qualifications of the offense as follows:(Asikin, 2016):

(1) Article 310 paragraph 1 of the Criminal Code regarding defamation.

(2) Article 310 paragraph 2 regarding written defamation.

(3) Article 311 regarding slander.

(4) Article 315 of the Criminal Code regarding minor insults.

(5) Article 316 of the Criminal Code regarding insults to state officials.

(6) Article 317 concerning complaints of slander to the authorities.

(7) Article 318 concerning giving rise to false suspicions.

(8) Article 320 concerning defamation of dead person.

In the a quo case, the Constitutional Court Decision Number 50/PUU-VI/2008 provides a limitation on the scope of insult and/or defamation when referring to Article 310 and Article 311 of the Criminal Code (Wibowo, 2012). Article 310 of the Criminal Code stipulates as follows:

“(1) Whoever intentionally offends someone person's honor or character by accusing them of something, the intent of which is apparent so that it is known to the public, faces a maximum sentence of nine months in prison or a maximum fine of four thousand five hundred rupiahs for libel"

The criminal acts contained in Article 310 paragraph (1) of the Criminal Code have the following elements:(Zainal, 2016):

a. The subjective element is intentional

b. The objective element is whoever 
c. Offend someone's honor or reputation by accusing someone of something

d. So that it is known to the public

As described above, the subjective element of a criminal act in Article 310 paragraph (1) of the Criminal Code is an intentional element (opzettelijk) (Disemadi \& Jaya, 2019). It can be seen that the intentional element (opzettelijk) is placed in the formulation of a criminal act regulated in Article 310 paragraph (1) of the Criminal Code which includes actions such as attacking someone's honor or good name by accusing something and so that it is known to the public. The objective element of a criminal act intentionally (opzettelijk) offends the reputation of a person by accusing something and so that it is known to the public as regulated in Article 310 paragraph (1) of the Criminal Code is an element of whoever. Whoever here is a person or persons, which if the person or persons fulfills the elements of a criminal act contained in Article 310 paragraph (1) of the Criminal Code, that person or persons can already be classified as the perpetrator of the crime.

Article 311 of the Criminal Code regulates the following:

"(1) If that commit a crime of libel or written defamation it is allowed to prove what is alleged is true, or no prove about it, and accusations are made contrary to what is known, then he is threatened with slander with a maximum imprisonment of long four years"

\subsubsection{ITE Law}

The criminal act of defamation in the ITE Law is regulated in Article 27 Paragraph (3) which regulates the following:

"Everyone intentionally and without the right to distribute and/or transmit and/or make accessible electronic information and/or electronic documents that have a charge of contempt and/or defamation"

The criminal acts contained in Article 27 paragraph (3) have the following elements:
a. The subjective element is intentionally
b. The objective element is everyone
c. Distribute and/or transmit and/or make accessible electronic information and/or electronic documents
d. Has the insults and/or defamation.

The intentional element (opzettelijk) is a subjective element and includes a form of error. The consequences of this form of error can have an impact on the severity of the punishment threatened (Andrianto, 2013). In the a quo article the form of error is clearly stated, therefore the public prosecutor must prove that there was an intentional act in the prohibited act. The theory of intentionality has 2 (two) concept, namely:

a. Will theory (wils theorie)(Hendrawan et al., 2015) 


\section{POLICY, LAW, NOTARY AND REGULATORY ISSUES (POLRI) \\ VOLUME 1 ISSUE 1 (2022)}

Intentionally is the will to make an action and the will can trigger a result of the action. In other words, it can be said to be intentional if the result of an action is desired, and it may be said that the result is desired if the result is the true intention of the action taken.

b. Theory of knowing (voorstelling theory)

Intentionally is the will to act by knowing the elements required by law

Another subjective element is without rights. This word is used to show the illegitimate nature of an action or intention. This is in line with the two groups classified by van Hamel regarding the opinion of wederrechtelijk, namely (Hendrawan et al., 2015):

a. Positive understanding

Simons defines it as "against the law" or Noyon which defines it as "violating the rights of others"

b. Negative understanding

Interpreting it as "not based on law" or "without rights" such the understanding adopted by Hoge Raad.

The objective element of a criminal act as regulated in Article 27 paragraph (3) of the ITE Law is everyone, what is meant by everyone in this Article refers to Article 1 number 21 of the ITE Law which stipulates as follows "people are individuals, whether Indonesian citizens, citizens of foreign countries, as well as legal entities." follows:

The criminal threat is regulated in Article 45 paragraph (1) which regulates as

"Everyone who fulfills the elements as referred to in Article 27 paragraph (1), paragraph (2), paragraph (3), or paragraph (4) shall be sentenced to a maximum imprisonment of 6 (six) years and/or a maximum fine of Rp. 1,000. ,000,000.00 (one billion rupiah)"

The ITE Law is a regulation that aims to regulate criminal acts in the field of information and electronic transactions, because the object of the act and the object of the crime are information and/or electronic documents. Base on this point of view, related with the location or nature of the prohibition, the legal interest that Article 27 Paragraph (3) wants to protect is a legal interest so that insults or defamation do not occur on the internet.

The element of "distributing and/or transmitting and/or making accessible electronic information and/or electronic documents" was originally a verb that became an element of a prohibited act not being described in more detail. However, for the sake of legal certainty, in the end, this phrase was added with an explanation, namely:

a. What is meant by "distributing" is sending and/or disseminating Electronic Information and/or Electronic Documents to many People or various parties through Electronic Systems. 
b. What is meant by "transmitting" is sending Electronic Information and/or Electronic Documents addressed to one other party through the Electronic System

c. What is meant by "make accessible" are all actions other than distributing and transmitting through Electronic Systems that cause Information and/or Electronic Documents to be known to other parties"

The element of "having insults and/or defamation" at first led to the draft regulated in the articles in the Criminal Code, then the Constitutional Court gave an interpretation that this article could not be separated from the norms of criminal law as regulated in Article 310 and Article 311 of the Criminal Code, then the legislators add an explanation section of Article 27 paragraph (3) that the provisions in this paragraph refer to the provisions for defamation and/or slander as regulated in the Criminal Code.

\subsection{The legitimacy of a corporation as a reporter in a criminal act of defamation based on the ITE Law?}

Before discussing the legitimacy of a corporation as a reporter in a criminal act of defamation based on the ITE Law, we need to first discuss what a corporation is. Initially, the Criminal Code did not identify corporations as the subject of criminal acts. However, along with the times and science, the legislators began to include corporations as the subject of criminal acts outside the Criminal Code (Ningrum, 2018), because many legislators have the idea that humans can commit criminal acts with corporations as the means. Corporations as the subject of criminal acts, apart from being formulated outside the Criminal Code, are also formulated in the 2019 RKUHP (Widowaty, 2012), namely Article 45 to Article 50 of the 2019 RKUHP. Regarding the theory of corporate criminal liability, there are several theories as follows (Nasution, 2015):

1. "Strict Liability" Theory

Stricy Liability theory or absolute responsibility theory applies if a criminal act is committed by an employee to carry out or carry out his duties for and on behalf of the corporation without the need to see the fault in the corporation when committing a crime. The imposition of criminal liability is imposed without the need to prove the element of guilt. This theory deviates from the general principle of criminal law, namely the principle of "geen straf zonder schuld" or "no crime without fault". There is a need for an expansion of criminal liability so that if the defendant is a corporation, he does not have mens rea. Mens rea does not need to be proven because with the existence of mens rea the process of proof becomes more difficult for crimes related to public peace, compliance with certain regulations is required for the peace of society, and the many problems caused by corporate actions.

2. The "Vicarious Liability" Theory

Vicarious Liability is a model of Stricy Liability, namely the actions of company representatives, employees, or someone who receives direction from the company or 


\section{POLICY, LAW, NOTARY AND REGULATORY ISSUES (POLRI) \\ VOLUME 1 ISSUE 1 (2022)}

anyone who is permanently related to the company can be related or mandated by accountability for certain actions of someone who commits an act.

3. Identification Theory

Identification Theory asserts that the mens rea owned by the officials of a corporation is also owned by the corporation. For example, the board of directors

4. Aggregation Theory

This theory applies if the employees together have fulfilled the elements of "actus reus" and "mens rea" then the corporation is responsible based on one act or several employees who have fulfilled the elements of the crime. This is a development of Strict Liability which can account for the corporation on the basis of a person's actions cumulatively. The important thing in this theory is the actus reus and mens rea and in this theory it is obligatory to meet the requirements for the corporation to be held criminally responsible.

5. Delegation Theory

Delegation Theory is a form of Identification Theory in a very broad corporation, where more than one can be said to be the controlling or "directing mind"

6. The theory of Corporate Culture

This theory refers to evaluation, it is contained in the Australian Penal Code subsection 12.3(6). What is meant by corporate culture is an attitude, policy, rule, and course of practice behavior that exists within the corporation.

Regarding the criminal liability of corporations in committing criminal acts of defamation through the internet, it is contained in Article 1 number 21 of the ITE Law which stipulates that "people are individuals, whether Indonesian citizens, foreign citizens, or legal entities". its arrangement in the ITE Law is regulated in Article 27 Paragraph (3) which at the beginning of the provision contains an element of "everyone"(PRIYATNO \& SH, 2020). So that based on the explanation that has been described, corporations can become the subject of criminal acts other than individuals because there is a shift in views regarding only individuals who can be held criminally responsible.

Meanwhile, regarding whether a corporation can become a reporting party in a criminal act of defamation based on the ITE Law, we must refer to the Joint Decree of the Minister of Communication and Information of the Republic of Indonesia, the Attorney General of the Republic of Indonesia, and the Head of the State Police of the Republic of Indonesia Number KB/2/VI/ 2021 Regarding Guidelines for the Implementation of Certain Articles in Law Number 11 of 2008 concerning Information and Electronic Transactions as Amended by Law Number 19 of 2016 concerning Amendments to Law Number 11 of 2008 concerning Information and Electronic Transactions (hereinafter referred to as SKB 2 /VI/2021). In letter a the implementation guidelines of Article 27 Paragraph (3) of the ITE Law stipulates as follows "according to the considerations of the Constitutional Court's decision Number 50/PPU-VI/2008 of 2008, and the Elucidation of Article 27 paragraph (3) of the ITE Law, the meaning of the content of insults and/or defamation must refer to and cannot be separated from the provisions contained in Articles 310 and 311 of the Criminal Code. Article 310 of 
the Criminal Code is an offense against someone's honor by accusing something to be known to the public. Meanwhile, Article 311 of the Criminal Code relates to the act of accusing someone whose accusation is known to be untrue by the perpetrator. Moreover, in letter $\mathrm{f}$ the implementation guidelines of Article 27 paragraph (3) of the ITE Law stipulates as follows "the victim as a reporter must be an individual with a specific identity, and not an institution, corporation, profession, or position".

If we refer to the a quo arrangement, it can be seen that corporations cannot be the reporting party in criminal acts of defamation based on the ITE Law. There is a reason why a corporation cannot be a reporting party in a criminal act of defamation based on the ITE Law, the first when we refer to Article 310 of the Criminal Code there is an element of "one's good name" in the Criminal Code that a person cannot be interpreted as a corporation, because in The corporate Criminal Code has not been identified as a legal subject.

\section{CONCLUSION}

The regulation of criminal acts of defamation is regulated in the Criminal Code and UU ITE, corporations cannot be the reporting party in criminal acts of defamation based on the UU ITE because based on letter a the implementation guidelines of Article 27 Paragraph (3) SKB No. 2/VI/2021 concerning guidelines for the implementation of the ITE Law stipulates that the meaning of the content of insults and/or defamation must refer to the provisions of Articles 310 and 311 of the Criminal Code in addition to letter $\mathrm{f}$ of the implementation guidelines of Article 27 Paragraph (3) of the ITE Law which governing that victims who can become whistleblowers are only individuals with a specific identity so that the corporation cannot be a reporting party under the ITE Law. Corporations cannot be the reporting party should be included in the article explanation to be binding in an arrangement because the nature of the DECREE containing implementation guidelines is only binding on law enforcement only.

\section{REFERENCES}

Andrianto. (2013). Menguji Konsep Pertanggungjawaban Pidana Korporasi. Jurnal Yuridika , 3(28).

Asikin, Z. (2016). Pengantar metode penelitian hukum.

Disemadi, H. S., \& Jaya, N. S. P. (2019). Perkembangan Pengaturan Korporasi Sebagai Subjek Hukum Pidana Di Indonesia. Jurnal Hukum Media Bhakti.

Hendrawan, M. B., Syahrin, A., Ginting, B., \& Mulyadi, M. (2015). Hubungan antara Kesengajaan terhadap Pertanggungjawaban Pidana dalam Kasus Kecelakaan Lalu Lintas di Jalan yang Menyebabkan Hilangnya Nyawa Orang Seseorang. USU Law Journal, 3(1), 56-73.

Maskun, S. H. (2013). Kejahatan Siber (Cyber Crime) Suatu Pengantar. Jakarta, Kencana.

Nasution, E. S. (2015). Pertanggungjawaban Pidana Korporasi dalam Tindak Pidana Pencucian Uang. Jurnal Mercatoria, 8(2), 132-144. 
Ningrum, H. W. (2018). Sejarah dan Perkembangan Pertanggungjawaban Korporasi. Volksgeist: Jurnal Ilmu Hukum Dan Konstitusi, 1(2), 139-156.

PRIYATNO, D. R. D., \& SH, M. H. (2020). Pertanggung jawaban pidana korporasi. Kencana Prenada Media Group.

Samudra, A. H. (2020). Pencemaran Nama Baik Dan Penghinaan Melalui Media Teknologi Informasi Komunikasi Di Indonesia Pasca Amandemen UU ITE. Jurnal Hukum \& Pembangunan, 50(1), 91-105.

Supanto, S. (2016). Perkembangan Kejahatan Teknologi Informasi (Cyber Crime) dan Antisipasinya dengan Penal Policy. Yustisia Jurnal Hukum, 5(1).

Wibowo, A. (2012). Kebijakan kriminalisasi delik pencemaran nama baik di Indonesia. Pandecta Research Law Journal, 7(1).

Widowaty, Y. (2012). Pertanggungjawaban Pidana Korporasi Terhadap Korban Dalam Kasus Tindak Pidana Lingkungan Hidup. Jurnal Yudisial, 5(2), 154-169.

Zainal, A. (2016). Pencemaran Nama Baik Melalui Teknologi Informasi Ditinjau Dari Hukum Pidana. Al-'Adl, 9(1), 57-74. 